\title{
The Influence of Company Size, Company Growth, Price to Book Value, Investment Opportunity Set, and Operating Cash Flow Againts Price Earnings Ratio in Food and Beverage Sub Sector Manufacturing Companies Listed In BEI from 2015 To 2017
}

\author{
Andini Nurwulandari \\ Universitas Nasional Jakarta, Indonesia \\ andinmanajemen@gmail.com
}

\begin{abstract}
This study aims to see how the Price Earning Ratio is affected by company size, growth, price to book value, investment opportunity set, and operating cash flow. The authors used panel data regression to analyze data from 2015 to 2017, 13 food and beverage firms were listed on the Indonesia Stock Exchange. According to the data that have been collected, company size, company growth, and price to book value all have a positive and significant effect on the Price Earning Ratio. Meanwhile, the Investment Opportunity Set and Operating Cash Flow have no impact on the Price Earning Ratio.
\end{abstract}

Keywords

price earning ratiq, company size; company grouth; price to book value; investment opportunity set; and operating cash flow

\section{Introduction}

The economic development of a country can be measured in many ways, one of which is by knowing the level of world capital market development. The capital market is a place for investors to conduct investment activities. Investors in investing funds into a company will be faced with return on investment in the form of dividends and capital The economic development of a country can be measured in many ways, one of which is by knowing the level of world capital market development. The capital market is a place for investors to conduct investment activities. Investors in investing funds into a company will be faced with return on investment in the form of dividends and capital. (Angelia and Toni, 2020)

Every company always tries to maximize the benefits it gets. Various strategies are applied to achieve these goals. The company will always keep its performance looking good in the eyes of its stakeholders. But in reality, companies are often faced with various obstacles that can cause a decline in performance and even financial difficulties and eventually go bankrupt. And of course the company will try to cover up this unhealthy condition from its stakeholders. One of them is by way of earning management (Utami in Sitaanggang, 2020)

The automotive industry's current growth and expansion have accelerated the economy's speed and increased market demand for goods (Vogel, 1994). This food and beverage business is still in order on a day-to-day basis. Food and beverage companies are a subset of the consumer goods industry (Consumer Goods), which transforms raw materials into finished goods (Filippaios \& Rama, 2008). This also happens in Indonesian food and beverage sub-sector manufacturing firms, which quickly expand and face fierce competition from domestic and imported goods (Zuhri et al., 2020). Food and beverage producers' costs and revenues would be affected by increased consumer demand of their interests. According to forecasts, food and beverage firms are still businesses that are 
needed in everyday life, so there is little risk of losing revenue. Investors would consider this when determining whether or not to invest in a business (Sagara, 2017).

Companies require specific objectives to accomplish something needed and planned. Any business has a mission, and a thriving business aims to maximize its wealth or value. Potential investors can regard a company with a high company valuation as a good company because it can describe good results (Prasetyorini, 2013). This would make it easier for the group to find buyers. Prospective investors can quickly assess a company's health by examining the image painted by its stock price. The valuation of a stock rises in tandem with its share price (Sudiyatno, 2010).

To decide which business stock to purchase, sell, and keep, investors need various facts about share price trends. The accurate stock valuation will reduce risk while still allowing investors to make a fair return (Purwaningrum, 2011). When determining whether or not stock prices are reasonable, a variety of models and methods can be used. The priceearnings ratio is the primary analyses used.

PER is one of the essential metrics in quantitative stock analysis, and it's a component of the value ratio used to evaluate financial statements. By comparing the price per share to the net profit per share, the price earning ratio is used to decide whether an investment is profitable or not. The price-making percentage varies depending on retail rates and the company's net profit expectation; if the price rises, the projection of fixed profit rises ( Leibowitz \& Kogelman, 1990; Wu, 2014). Thus, stock price movements will result in changes in the PER of a company. Investors must respond if a stock price movement results in a low PER and how investors will react if the PER is high. For investors, a low PER will provide its contribution because, in addition to being able to buy shares at relatively low prices, the possibility of obtaining capital gains is also greater so that investors can own many shares from various companies that go public. On the other hand, the issuer wants a high PER when it goes public to show that the company's performance is good enough to hope that the stock price will also be increased (Prasetyorini, 2013; Safitri, 2013).

The aim of this analysis was to investigate the variables that Impact the PER as a metric to consider for investors who will invest in a company, while several factors affect the price making ratio such as company size, company growth, price to book value, investment opportunity. Sets, and operating cash flows.

\section{Review of Literature}

\subsection{Company Size (C.Z.)}

The term "business size" refers to a size, scale, or metric representing a company's size depending on several factors, including net assets, log size, stock value, shares, gross sales, total revenue, total resources, and others (Basyaib, 2007; Machfoedz, 1994; Schiffer \& Weder, 2001). According to a scale that can be measured by the number of net assets and revenue, a more extensive business would have a surplus in the source of funds raised to cover its interest in making a profit (Ibrahim, 2008). Its size can represent the financial features of an organization. Obtaining funding in the capital market would be better for large, well-established firms than for small businesses. Big businesses have more versatility as a result of this ease of entry.

Large corporations are easier to identify and gain entry into the capital markets. As a result, there is a low chance of bankruptcy. One of the considerations that investors weigh when making investment decisions is stock valuation, specifically PER (Riyanto, 2001). Small businesses would have a more challenging time obtaining funding in the capital 
market than large corporations that have been around for a long time. A more significant business can, however, have better insight into customers who invest in a company. Furthermore, analysts believe that big corporations are more robust and capable of producing greater earnings than small corporations. This rise would boost PER in the future, and consumers will see it favorably.

$\mathrm{H} 1$ = Company size has a positive effect on Price Earning Ratio

\subsection{Company Growth (C.G.)}

According to Brigham and Houston (2009), business growth is described as the change in the company's total assets (increase or decrease). According to the pecking order principle, the company's growth has a favorable impact on funding decisions. Companies with high rates of business growth must depend on foreign funding further in this situation. The larger the demand for funds to support investment, the higher the company's growth rate. This point is backed up by Utami (2011), who claims that a company's growth is defined by how it spends the funds it has for operational and investment activities. Increasing the number of reserves, both existing and long-term, necessitates financing from either internal or external sources (Suprantiningrum, 2013).

The increasing assets held by the group due to the company's increased operations demonstrate the company's growth. Since healthy growth is a symbol of an organization's progress. As seen from an investor's viewpoint, a company's success is an indication that the company has bright prospects. Companies with high expected growth rates aim to produce a lot of cash flow, attracting buyers. Development has a solid and optimistic impact on stock price movements, implying that investors react favorably to reports about a company's growth, resulting in higher stock values and an effect on the Price Earnings Ratio's valuation.

$\mathrm{H} 2$ = Company growth has a positive effect on Price Earning Ratio

\subsection{Price to Book Value (PBV)}

The price to book value ratio describes how much the public appreciates a company's book value. The higher this ratio is, the more confident the market is of the company's future. When a company is doing well, the PBV ratio rises above one, indicating that the stock market valuation exceeds the book value (Block, 1995). The larger a stock's Price to Book Value ratio, the higher the investor's opinion of that firm. Book value-based stock valuation can be through the Price to Book Value indicator (Murhadi, 2009).

$$
\text { PBV }=\frac{\text { Price per Share }}{\text { Book Value per Share }}
$$

The approximate valuation of equity-based on a measure of a stock's book value and its share price is seen as Price Book Value (PBV). The higher the company's value, the higher the PBV (Rahma \& Djazuli, 2014). The higher the PBV ratio, the higher the business valuation, which attracts investors or prospective investors to invest in the company because sensible investors choose issuers with high PBVs. As a result of this attraction, the number of new buyers or investors who hold business shares will rise, increasing the Price Earning Ratio (Oktaviani \& Agustin, 2017).

$\mathrm{H} 3=$ Price to Book Value has a positive effect on Price Earning Ratio 


\subsection{Investment Opportunity Set (IOS)}

After Myers (1977) proposed that a company's value is a blend of available assets and potential future investment opportunities, the Investment Opportunity Set (IOS) was born. Gaver \& Gaver (1993) stated, IOS is a projection of firm worth, which is calculated by previous management and based on future expenditures. The future looks bright. Adam \& Goyal (1992) stated that in line with this opinion, the component of firm value is a result of investment choices for future use and is a proxy for IOS itself. It can be concluded from the two opinions of experts above that IOS is an investment decision made by companies to generate value.

Investment prospects include growth opportunities. If issuers plan for the long run, they may use a price earning ratio to assess equity prices. Investors will flock to purchase shares if the firm has a high price-to-earnings ratio (Udayani \& Suaryana, 2013). The presence of investment opportunities that can produce Income is the nature of a company's success (Nugroho \& Hartono, 2002). Investment opportunities in the company are related to selecting the desired investment from a group or set of investment opportunities, selecting one or more investment alternatives considered the most profitable. The higher the investment opportunity, the company will have value in the future and be highly valued by investors.

H4 = Investment Opportunity Set has a positive effect on PER

\subsection{Operating Cash Flow (OCF)}

According to PSAK No. 2 paragraph 12 (IAI, 2009). Cash receipt and cash transfer transactions are divided into three categories of the cash balance statement: spending, saving, and borrowing. The benefits of cash from sales that produce revenue and losses, which are then used in calculating service, are included in operating operations. This cash source is widely regarded as the most accurate indicator of a company's willingness to raise additional funding to sustain operations (Yuwana, 2014). Transactions involving the acquisition and selling of products, for example (Adiwiratama, 2012). The operational cash balance formula is as follows:

$$
\text { Operating Cash Flow }=\frac{\text { OCF }- \text { oCF } t-1}{\text { oCFt }-1}
$$

There is a shift in the flow of operating operations that sends a clear signal to customers, causing them to purchase company stock. Investors will see how the company's financial duration will be in the future and whether it will deliver positive or negative cash flows based on company statistics from the present period, thanks to the organization's ability to forecast future operating cash flows.

H5 = Operating cash flow has a positive effect on Price Earning Ratio

\subsection{Price Earning Ratio (PER)}

One of the most fundamental metrics of quantitative portfolio valuation is the PER. Simply put, PER is a "comparison of the share price and the company's net profits,"(Arisona, 2013). Since the measure is based on the firm's net profits, understanding the PER of an issuer allows one to determine if the price of a stock is fair in actual terms and in the future. Experts define the Price Earning Ratio is a measure of the selling price (Prasetyorini, 2013). 
The profit growth rate and the dividend distribution rate are the two main variables that affect PER. The PER value would rise in tandem with the rate of profit growth. Then you'll calculate the Dividend Payout Rate, this is the dividend growth per share divided by earnings per share growth. Divide the share price by the earnings per share to get this Price Earning Ratio. As a result, PER will show the current share price relative to the amount of times net profits over the year for each share. The formula for calculating the Price Earning Ratio is as follows:

PER $=$ Share Price $:$ EPS (Earning Per Share)

\section{Research Methods}

This study covered 18 food and beverage firms that were listed on the Indonesia Stock Exchange (BEI) between 2015 and 2017. The sample for this study was chosen using purposeful sampling, which included the following criteria: 1) Food and beverage sub-sector companies that were listed on the Indonesia Stock Exchange between 2015 and 2017, and 2) Food and beverage sub-sector companies that reported financial statements on a regular basis between 2015 and 2017. The samples analyzed were 13 businesses that met these requirements. Quantitative analysis of descriptive mathematical equations is the data analysis approach used. For data analysis, the Eviews v9 output application is used, and multiple linear regression analysis is the data analysis method used (Sugiyono, 2014).

\section{Results and Discussion}

\subsection{Descriptive Analysis}

Slope of distribution are all descriptive statistics that provide you a quick rundown of your results (Ghozali, 2016). Price Earnings Ratio (Y), Company Size (X1), Company Growth (X2), Price to Book Value (X3), Investment Opportunity Set (X4), and Operating Cash Flow (X5) are the descriptive figures for the observed variables (X5). The findings of descriptive statistical testing of the variables in this analysis using Eviews version 9 are as follows:

Table 1. Descriptive Statistics of Research Data

\begin{tabular}{|l|c|c|c|c|c|c|}
\hline & PER & CZ & CG & PBV & IOS & OCF \\
\hline Mean & 15.17462 & 29.22410 & 10.56615 & 5.015897 & 477.2582 & -33.46923 \\
\hline Median & 16.78000 & 29.02000 & 7.880000 & 1.580000 & 202.6600 & 6.660000 \\
\hline Maximum & 66.30000 & 32.27000 & 62.03000 & 30.17000 & 3016.820 & 422.9300 \\
\hline Minimum & -35.11000 & 25.89000 & -1336000 & 0.210000 & 21.00000 & -3709800 \\
\hline Std. Dev & 19.52811 & 1.853750 & 15.75304 & 7.720021 & 704.7340 & 120.4593 \\
\hline Skewness & -0.384453 & 0.091464 & 1.426002 & 2.304030 & 2.554328 & 0.055790 \\
\hline Kurtosis & 4.222322 & 1.963811 & 5.587166 & 7.230617 & 8.590833 & 7.833793 \\
\hline Jarque-Bera & 3.388592 & 1.799119 & 24.09445 & 63.59006 & 93.20315 & 37.98926 \\
\hline Probability & 0.183729 & 0.406749 & 0.000006 & 0.000000 & 0.000000 & 0.000000 \\
\hline Sum & 591.8100 & 1139.740 & 412.0800 & 195.6200 & 18613.07 & -1305300 \\
\hline Sum Sq. Dev & 14491.19 & 130.5827 & 9430.017 & 2264.752 & 18872701 & 551396.5 \\
\hline Observations & 39 & 39 & 39 & 39 & 39 & 39 \\
\hline
\end{tabular}

Source: Eviews v9 Output Results 
According to Table 2, the Price Earning Ratio of -35.11000 and a max 66.30000, with an average of 15.17462 and a standard deviation of 19.52811 . The average value of 29.22410 , with a standard deviation of 1.853750 , is obtained from the company scale, which has a minimum value of 25.89000 and a maximum value of 32.27000 . The company's growth reached a low of -13.36000 and a high of 62.03000 , with an average of 10.56615 and a standard deviation of 15.75304. The Price to Book Value had a low of 0.210000 and a high of 30.17000, with an average of 5.015897 and a standard deviation of 1.580000. The Investment Opportunity Set had a minimum value of 21.00000, a median value of 3016.820 , and 477.2582 with a standard deviation of 202.6600 , with 202.6600. Operating Cash Flow had a low of -370.9800 , a high of 422.9300 , and a median of 33.46923 , with a confidence interval of 6.660000 .

\subsection{Classic Assumption Test}

a. Multicollinearity Test

The results of the multicollinearity test are listed below:

Table 2. Multicollinearity Test Results

Variance Inflation Factors

Date: 02/04/19 Time: 01:18

Sample: 20152053

Included observations: 39

\begin{tabular}{cccc}
\hline \hline Variable & $\begin{array}{c}\text { Coefficient } \\
\text { Variance }\end{array}$ & $\begin{array}{c}\text { Uncentered } \\
\text { VIF }\end{array}$ & $\begin{array}{c}\text { Centered } \\
\text { VIF }\end{array}$ \\
\hline \hline IOS & 0.003191 & 6.054004 & 4.116431 \\
PBV & 24.89600 & 5.522885 & 3.853393 \\
PER & 2.241540 & 3.595702 & 2.219952 \\
CG & 2.228739 & 2.099575 & 1.436365 \\
CZ & 214.7078 & 490.6674 & 1.916138 \\
C & 174436.9 & 464.9392 & NA \\
\hline \hline
\end{tabular}

Source: Eviews 19 Output Results

Based on Table 2, the centered VIF number from the Investment Opportunity Set is 4.116431, the Price to Book Value is 3.853393, the Price Earning Ratio is 2.219951, the Company Growth is 1.436365 , the Company Size is 1.916138 where the numbers are below 10. This shows that there is no multicollinearity in this study.

\section{b. Test for Heteroscedasticity}

The heteroscedasticity test determines if there is an inequality invariance and residuals or observations of other observations in the regression model. The Heteroscedasticity Test yielded the following results:

Table 3. Heteroscedasticity Test Results

Heteroskedasticity Test: Glejser

\begin{tabular}{llll}
\hline \hline F-statistic & 3.549706 & Prob. F(5,7) & 0.0644 \\
Obs`R-squared & 9.323014 & Prob. Chi-Square(5) & 0.0969 \\
Scaled explained SS & 3.868437 & Prob. Chi-Square(5) & 0.5685 \\
\hline \hline
\end{tabular}

Test Equation:

Dependent Variable: ARESID

Method: Least Squares 
Date: 02/04/19 Time: 01:36

Sample: 113

Included observations: 13

\begin{tabular}{crrrr}
\hline \hline \multicolumn{1}{c}{ Variable } & Coefficient & Std. Error & t-Statistic & Prob. \\
\hline \hline C & 95.79117 & 37.15052 & 2.578461 & 0.0366 \\
CZ & -0.029557 & 0.013436 & -2.199831 & 0.0637 \\
CG & -0.036423 & 0.082996 & -0.438856 & 0.6740 \\
IOS & -0.548222 & 0.232122 & -2.361786 & 0.0502 \\
OCF & 0.003377 & 0.012018 & 0.281023 & 0.7868 \\
RB-squared & 0.007616 & 0.014610 & 0.521271 & 0.6183 \\
Adjusted R-squared & 0.515123 & S.D. dependent var & 9.513685 \\
S.E. of regression & 4.300092 & Akaike info criterion & 6.175354 \\
Sum squared resid & 129.4356 & Schwarz criterion & 6.059188 \\
Log likelihood & -33.38472 & Hannan-Quinn criter. & 6.319934 \\
F-statistic & 3.549706 & Durbin-Watson stat & 2.123036 \\
Prob(F-statistic) & 0.064437 & & \\
\hline \hline
\end{tabular}

Source: Eviews v9 Output Results

The prob value is seen in table 3 above. The F statistic is 0.0644 , which is greater than 0.05 . As a result, it is possible to assume that this analysis is free of heteroscedasticity issues.

\section{c. Test Panel Data Regression with Random Effect Method}

A panel data regression model (pool) contains data from both cross-section power and time series. In the Random Effect model, the error terms of each organization allow for variations in imperceptibility. The following are the regression effects using the Random Effect:

Table 4. Panel Data Regression Test Results Model Random Effect Dependent Variable: PER?

Method: Panel EGLS (Cross-section random effects)

Date: 02/03/19 Time: 20:42

Sample: 20152017

Periods included: 3

Cross-sections included: 13

Total panel (balanced) observations: 39

Swamy and Arora estimator of component variances

\begin{tabular}{lcrrr}
\hline \hline Variable & Coefficient & Std. Error & t-Statistic & Prob. \\
\hline \hline C & -204.5697 & 53.36756 & -3.833223 & 0.0005 \\
CV? & 7.401765 & 1.867935 & 3.962539 & 0.0004 \\
C.G.? & 0.261431 & 0.112131 & 2.331483 & 0.0260 \\
PBV? & 0.912741 & 0.431117 & 2.117152 & 0.0419 \\
IOS? & -0.008095 & 0.005879 & -1.377008 & 0.1778 \\
OCF? & 0.012723 & 0.013820 & 0.920637 & 0.3639 \\
Random Effects (Cross) & & & & \\
-ALTO_C & & & & \\
AISA--C & & & & \\
_SKBM--C & -22.75591 & & & \\
-DLTA--C & 0.034315 & & & \\
-ICBP--C & 13.16155 & & & \\
_INDF--C & & & &
\end{tabular}




$\begin{array}{lr}\text {-MYOR--C } & -7.822221 \\ \text {-PSDN--C } & -9.971696 \\ \text { _ROTI--C } & -11.49371 \\ \text {-MLBI--C } & 6.252193 \\ \text { _STTP--C } & 9.121656 \\ \text {-ULTJ--C } & 13.97108 \\ \text { _CEKA--C } & 2.013954 \\ & 11.33597 \\ & -7.927369 \\ & 4.080191\end{array}$

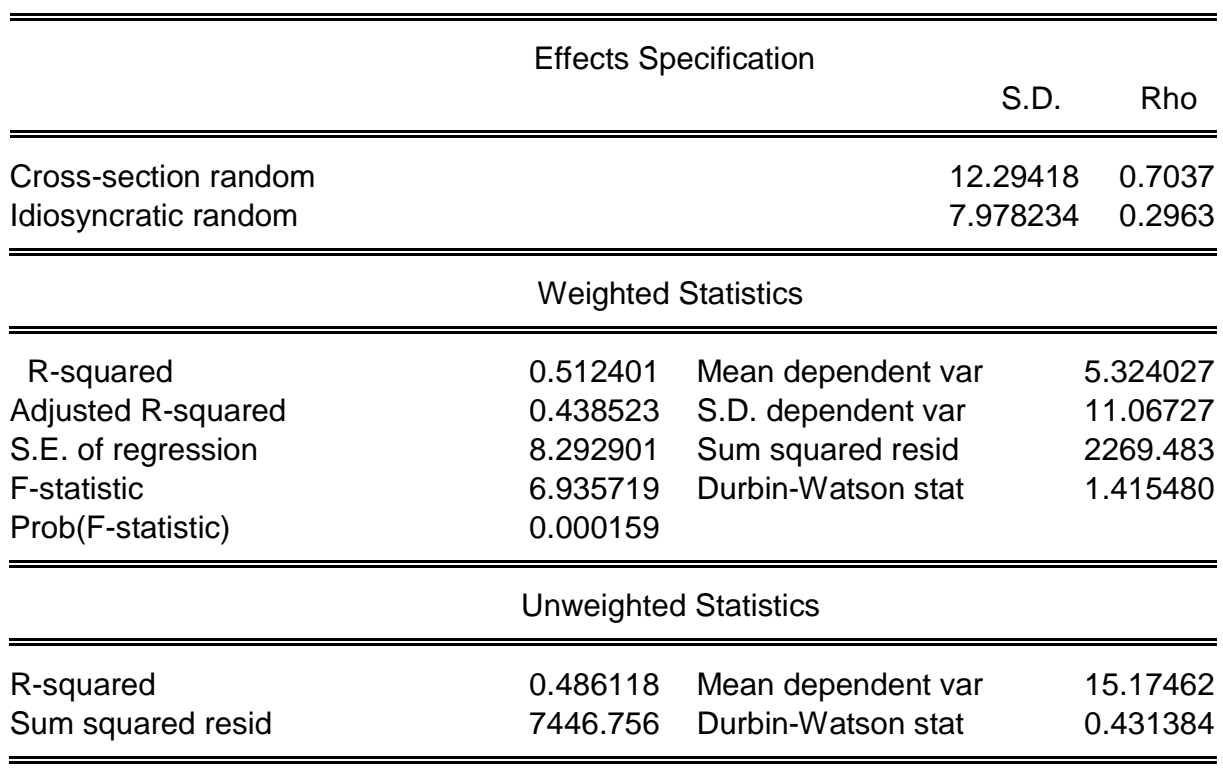

Source: Eviews v9 Output Results

Based on Table 4 of the Random Effect model above, the following equation can be obtained:

$\mathrm{PER}=-204.5697+\mathrm{Ci}($ Random Effect $)+7.401765 \mathrm{CZ}+0.261431 \mathrm{CG}+0.912741 \mathrm{PBV}-$ $0.00895 \mathrm{IOS}+0.012723 \mathrm{OCF}$

The constant value is -204.5697 , according to the regression results. This means that the Price Earning Ratio is -204.5697 as Company Size (UP), Company Growth (P.P.), PBV, Investment Opportunity Set (IOS), and Operating Cash Flow (AKO) are both kept steady.

1. Company size has a coefficient of 7.401765 with a probability of 0.0004 . As a result, it's easy to see how business size affects the Price Earning Ratio. This assumes that as the business grows in size, the Price Earning Ratio will grow in value. If a company's scale has shrunk, the Price Earning Ratio's worth will fall. And if the organization Size has grown by one unit, and the Price Earning Ratio will grow by 7.401765 assuming that the other variables remain stable. And vice versa.

2. Company growth has a coefficient of 0.261431 with a probability of 0.0260 . If the company's growth has increased, it will increase the value of the Price Earning Ratio. if the company's growth has decreased, it will decrease the value of the price earning ratio. And if the company growth has increased by 1 unit, the Price Earning Ratio will increase by 0.261431 .

3. With a significance ratio of 0.0419 , the Price to Book Value coefficient is 0.912741 . The Price Earning Ratio will rise as the PBV increases. The PER's value will be lower if the PBV has dropped. The PER would rise by 0.912741 if the Book Value Price has 
been increased by one unit. Assume the other variables remain stable. As a result, PBV has a strongt positive effect on the PER.

4. The Investment Opportunity Set has a coefficient of -0.00895 with a probability of 0.1778. If the Investment Opportunity Set has increased or decreased by 1 unit, it will not affect the Price Earning Ratio because the level of significance is 0.1778>0.05.

5. Operating Income has a chance of 0.3639 and a coefficient of 0.012723 . Since the importance threshold is $0.3639>0.05$, a one-unit rise or reduction in Operating Income has little effect on the Price Earning Ratio. As a result, Operating Cash Flow has little major impact on the Price Share Earnings.

\subsection{Hypothesis Test}

\section{a. Significance Test of Individual Parameters (T-Test)}

This test will be carried out in two testing stages for this research model, namely a significant difficulty with a probability for the p-value and a directional test for the coefficient value.

1) Business Size

The significance level is considered to be 95 percent $(=5 \%$ ) based on the regression results. The chance of a company's size is 0.0004 , where 0.05 . As a result, Ho was turned down, and Ha admitted. Furthermore, the Company Size coefficient, which is positive at 7.401765, can be seen. This means that as the size of the company grows. The Price Earning Ratio declines as the firm size decreases. As a result, it can be inferred that a business's size has a favorable and substantial impact on the Price Earning Ratio (H1 accepted).

2) Business Expansion

Company growth has a chance of 0.0260 , where 0.05 , at a significant stage of 95 percent ( $=5$ percent). As a result, Ho was turned down, and Ha admitted. Furthermore, the company's growth coefficient is 0.261431 , which is a positive value. This means that as the company's revenue grows, the price-to-earnings ratio will rise as well. When the company's growth slows, the price-to-earnings ratio will fall. As a result, it is possible to infer that business growth has a favorable and substantial impact on the Price Earning Ratio. (H2 is permitted.)

3) Price-to-Book-Value Ratio

Price to Book Value has a chance of 0.0419 , where 0.05 , with a significance ratio of 95\% ( = 5\%). After Ho is refused and $\mathrm{Ha}$ is accepted, the Price to Book Value coefficient is positive at 0.912741 . The PER declines as the PBV decreases. As a result, Price to Book Value has a favorable and essential impact on the Price Earning Ratio. (H3 has been received.)

4) Identifying Investment Opportunities

Price to Book Value has a chance of 0.1778 where $>0.05$ with a significance ratio of 95\% ( = 5\%). When Ho is accepted, and Ha is refused, the Investment Opportunity Set coefficient is -0.008095 , which is negative. The IOS has a negative and insignificant influence on the Price Earning Ratio. since the degree of importance is 0.1778>0.05. (H4 was rejected.)

5) Cash Flow from Operations

Price to Book Value has a chance of 0.3639 where $>0.05$ with a significance ratio of $95 \%(=5 \%)$. As a result, Ho was approved while Ha was refused. Furthermore, the operating cash flow coefficient, which is 0.012723 , is positive. Operating cash flow has a favorable and negligible impact on the Price Earning Ratio since the degree of importance is $0.3639>0.05$. (H5 was rejected). 


\section{Conclusion}

Company size has a favorable and substantial impact on Price Earning Ratio. This assumes that as the business grows in size, the Price Earning Ratio will increase in value. Similarly, as the company's scale has shrunk, the price-to-earnings ratio's valuation has shrunk. This demonstrates how a company's size influences stock valuation by investors. As a result, consumers believe that big corporations are more reliable and capable of better profit margins than small corporations. Company growth has a substantial and robust impact on the price earnings ratio. This means that as the company's growth accelerates, the Price Earning Ratio's value rises. If the company's growth slows, the price earning ratio's valuation drops. This is because the higher a company's net assets are, the more eager buyers are to spend their money in its stock, increasing the Price Earning Ratio. Price to Book Value has a favorable and substantial impact on the Price Earnings Ratio.

This suggests that the higher a stock's PBV ratio, the higher its opinion. The stock price of a business will rise as a result, and the earning price ratio of shares will rise. The Investment Opportunity Set has no impact on the Price Earning Ratio. This demonstrates that the PER is unaffected by the high or low value of the Investment Opportunity Collection. In food and beverage firms, operating cash flow has little bearing on the price-earnings ratio. This is because operational cash flow investors ignore managing cash flow data, so the price earning ratio's importance is unaffected by high and low operating cash flow.

\section{References}

Adam, T., \& Goyal, V. K. (2008). The Investment Opportunity Set and Its Proxy Variables. Journal of Financial Research, 31(1), 41-63.

Adiwiratama, J. (2012). Pengaruh Informasi Laba, Arus Kas dan Size Perusahaan terhadap return Saham (Studi empiris pada perusahaan manufaktur yang terdaftar di BEI). Jurnal Ilmiah Akuntansi dan Humanika, 2(1).

Angelia, N and Toni, N. (2020). The Analysis of Factors Affecting Dividend Policy in Food and Beverage Sector Manufacturing Companies Listed in Indonesia Stock Exchange in 2015-2017. Budapest International Research and Critics InstituteJournal (BIRCI-Journal). P. 902-910

Arisona, V. F. F. (2013). Faktor-Faktor yang Mempengaruhi Price Earning Ratio. Jurnal Ilmu Manajemen (JIM), 1(1).

Basyaib, Fachmi (2007). Keuangan Perusahaan Pemodelan Menggunakan Microsoft Excell. Jakarta: Kencana Prenada Media Group.

Brigham, E. F., \& Houston, J. F. (2009). Fundamentals of Financial Management, Concise Edition. Cengage Learning.

Filippaios, F., \& Rama, R. (2008). Globalisation or Regionalisation? The Strategies of The World's Largest Food and Beverage MNEs. European Management Journal, 26(1), 59-72.

Gaver, J. J., \& Gaver, K. M. (1995). Compensation Policy and The Investment Opportunity Set. Financial Management, 19-32.

Ghozali, I. (2013). Aplikasi Analisis Multivariate dengan Program SPSS. Semarang: Universitas Diponegoro Publisher.

Ibrahim, H. (2008). Pengaruh Tingkat Suku Bunga, Peringkat Obligasi, Ukuran Perusahaan Dan Der Terhadap Yield To Maturity Obligasi Korporasi Di Bursa Efek Indonesia Periode Tahun 2004-2006 (Doctoral dissertation, Program Pascasarjana Universitas Diponegoro). 
Leibowitz, M. L., \& Kogelman, S. (1990). Inside the P/E Ratio: the Franchise factor. Financial Analysts Journal, 46(6), 17-35.

Machfoedz, M. U. (1994). Financial Ratio Analysis and The Prediction of Earnings Changes in Indonesia. Kelola, 7(3), 114-134.

Murhadi, W. R. (2009). Studi Pengaruh Good Corporate Governance terhadap Praktik Earnings Management pada Perusahaan Terdaftar di PT Bursa Efek Indonesia. Jurnal Manajemen dan Kewirausahaan, 11(1), 1-10.

Myers, S. C. (1977). Determinants of Corporate Borrowing. Journal of financial economics, 5(2), 147-175.

Nugroho, J. A., \& Hartono, J. (2002). Analisis Hubungan Antara Gabungan Proksi Investment Opportunity Set Dan Real Growth Dengan Pendekatan Confirmacy Factor Analysis. Jurnal Riset Akuntansi Indonesia, 6(1), 69-92.

Oktaviani, P. R., \& Agustin, S. (2017). Pengaruh PER, EPS, DPS, DPR Terhadap Harga Saham Pada Perusahaan Pertambangan. Jurnal Ilmu dan Riset Manajemen (JIRM), 6(2).

Prasetyorini, B. F. F. (2013). Pengaruh Ukuran Perusahaan, Leverage, Price Earning Ratio dan Profitabilitas Terhadap Nilai Perusahaan. Jurnal Ilmu Manajemen (JIM), 1(1).

Purwaningrum, E. (2011). Factors Affecting Price Earning Ratio of Company's Share in the Manufacture Sector. Jurnal Ekonomi \& Bisnis PNJ, 10(1), 13434.

Rahma, E. Y., \& Djazuli, A. (2014). Analisis Variabel Fundamental yang Berpengaruh terhadap Price Earning Ratio (PER) sebagai Dasar Penilaian Saham pada Perusahaan Automotive and Allied yang Terdaftar di Bursa Efek Indonesia. Jurnal Aplikasi Manajemen, 12(3), 362-372.

Riyanto, B. (2001). Dasar-Dasar Pembelanjaan Perusahaan. Yogyakarta:BPFE

Safitri, A. L. (2013). Pengaruh Earning Per Share, Price Earning Ratio, Return On Asset, Debt To Equity Ratio dan Market Value Added terhadap Harga Saham dalam kelompok Jakarta Islamic Index tahun 2008-2011 (Doctoral dissertation, Universitas Negeri Semarang).

Sagara, I. (2017). Pengaruh Profitabilitas Dan Keputusan Investasi Terhadap Nilai Perusahaan Yang Dimoderasi Oleh Kebijakan Dividen Pada Perusahaan Makanan Dan Minuman Yang Terdaftar Di Bursa Efek Indonesia Periode 2012-2015 (Doctoral dissertation, Fakultas Ekonomi dan Bisnis Unpas).

Schiffer, M., \& Weder, B. (2001). Firm Size and The Business Environment: Worldwide Survey Results. The World Bank.

Sitanggang, S. et al. (2020). Analysis ofthe Influence ofManagerial Ownership, Audit Quality and Audit Committee on Income Management (Study on Manufacturing Companies in the Consumer Goods Sector Listed on the Indonesia Stock Exchange 2014-2018). Budapest International Research and Critics Institute-Journal (BIRCIJournal). P. 2521-2533.

Sudiyatno, B. (2010). Peran Kinerja Perusahaan Dalam Menentukan Pengaruh Faktor Fundamental Makroekonomi, Risiko Sistematis, Dan Kebijakan Perusahaan Terhadap Nilai Perusahaan (Studi Empirik Pada Perusahaan Manufaktur Di Bursa Efek Indonesia) (Doctoral dissertation, Universitas Diponegoro).

Sugiyono. (2014). Metode Penelitian Pendidikan Pendekatan Kuantitatif, Kualitatif Dan R\&D. Bandung: Alfabeta.

Suprantiningrum. (2013). Pengaruh Pertumbuhan Aktiva dan Ukuran Perusahaan Terhadap Struktur Modal Pada Perusahaan Perbankan. Jurnal Ilmiah Dinamika dan Bisnis, 1 (1): 32-43. 
Udayani, I. D., \& Suaryana, A. (2013). Pengaruh Profitabilitas Dan Investment Opportunity Set Pada Struktur Modal. E-Jurnal Akuntansi, 4(2), 299-314.

Utami, E. S. (2019, October). Analysis Capital Structure on Indonesia Stock Exchange. In 2019 International Conference on Organizational Innovation (ICOI 2019) (pp. 686690). Atlantis Press.

Vogel, S. J. (1994). Structural Changes In Agriculture: Production Linkages And Agricultural Demand-Led Industrialization. Oxford Economic Papers, 46(1), 136-156.

$\mathrm{Wu}, \mathrm{W}$. T. A. (2014). The P/E ratio and profitability. Journal of Business \& Economics Research (JBER), 12(1), 67-76.

Yuwana, V. (2014). Analisa Kemampuan Laba Dan Arus Kas Operasi Dalam Memprediksi Arus Kas Operasi Masa Depan. Business Accounting Review, 2(1), 1-10.

Zuhri, S., Juhandi, N., Sudibyo, H. H., \& Fahlevi, M. (2020). Determinasi Harga Saham Perusahaan Manufaktur Subsektor Makanan dan Minuman. Journal of Industrial Engineering \& Management Research, 1(2), 25-34. 